\title{
Inspiring students ONE MOLECULE AT A TIME
}

$\mathrm{I}_{\mathrm{r}}^{\mathrm{m}}$ emember my first conversation with Dr. Richard "Dick" Lagow like I remember every detail of my first apartment: It was a pivotal moment in my life. As a junior biochemistry major at The University of Texas at Austin, I asked him about serving as my mentor for Chemistry $369 \mathrm{~K}$ - an upper division, undergraduate research elective course available to students lucky enough to find a professor willing to supervise them.

Although I originally encountered Dr. Lagow as the instructor of my first year chemistry laboratory a couple of years prior, I had never actually talked to him. In fact, had not my organic chemistry professor suggested I ask him about undergraduate research, I never would have mustered up the courage to speak to the discoverer of the fourth allotrope of carbon and one of the world's leading fluorine chemists.

I remember tiptoeing into his office, where I found him sifting through papers at his desk.

"Hi, Dr. Lagow. My name is Frieda Wiley, and I was a student in your freshman chemistry lab," I said. "I'm now a junior wanting to take $369 \mathrm{~K}$, and I was wondering if you would be willing to let me work in your lab." My voice trailed off in anticipation of the imminent rejection. After all, several other professors had turned me down, so why should this encounter be any different?

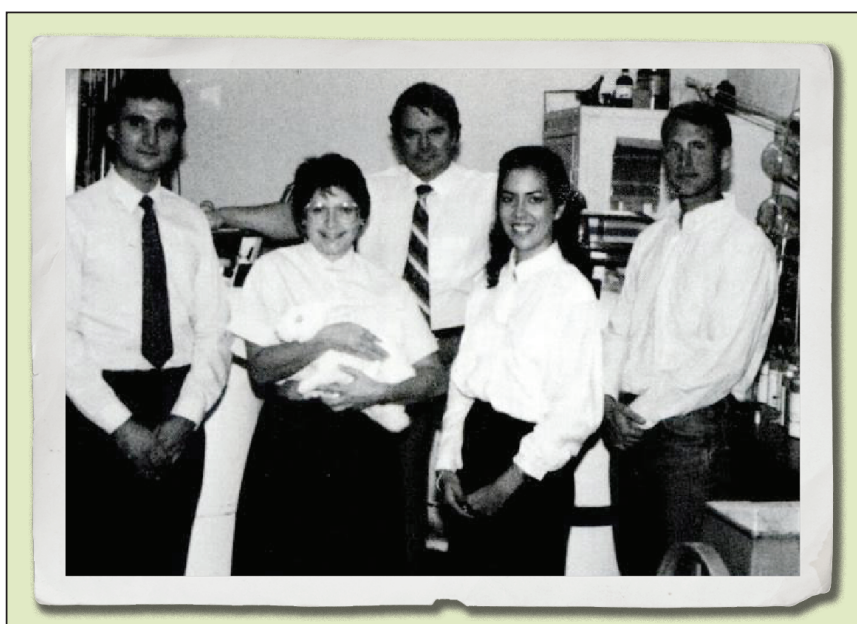

Richard Lagow stands behind his research team. (From left to right): Paul Capano, Sharon Hoffman holding a laboratory rabbit implanted with bone replacement material developed by the research team, Dagmar Rosa, and future physician Jay Bender. Reprinted with permission from The Alcalde (The University of Texas at Austin alumni magazine) 77 (4) (March/April 1988). Source: Call Number: LH1A432.

Dr. Lagow was the first — and only — professor I ever had who boldly stated that science students "should be breaking laboratory equipment," as he adamantly felt these unfortunate mishaps were a normal part of the learning process. Given that the competitive climate of science enhanced my nervous tendencies, I found his candor both revolutionary and liberating.

Most importantly, Dr. Lagow gave me the opportunity to conduct undergraduate research in his laboratory when other professors had told me no. In the 20 years since his passing in 2010, I have often contemplated why Dr. Lagow was willing to take a chance on an often-misunderstood biochemistry student. He thought highly of his students and encouraged us to think outside the box.

My story of self-discovery because of Dr. Lagow's tutelage is just one of many. The year was 1984 - an era that bore witness to a deluge of scientific breakthroughs and tragedies. The introduction of DNA fingerprinting would eventually revolutionize forensic science. A Union Carbide plant explosion in Bhopal, India, released 30-plus tons of toxic gases into the air in what remains the deadliest chemical plant "explosion" in history. AIDS earned both a name and an identity before transforming into a global health crisis. Apple would unveil its Macintosh personal computer

He looked over, making direct eye contact, and said, "Yes."

"Yes?" I repeated. I was certain he had misunderstood my question.

"Mm-hmm," he said, rising from his chair. "You like chemistry, don't you?" His question sounded more like a declaration than an interrogative statement.

"Yes," I responded, still stunned.

As he organized papers in his file cabinet, he began telling me how he got his start in chemistry. While he was a college football star who attended Rice University on a chemistry and football scholarship, Dr. Lagow initially began conducting research as an undergraduate chemistry major. His college years reflected a precocious talent: He managed to complete his doctoral studies while still an undergraduate student at Rice University. However, his doctoral degree was awarded two years later than his bachelor's degree because of the university's two-year minimum residency policy. in the United States - launching the first personal computer to employ a graphical user interface. And Richard Lagow, a fluorine chemist, scientist, and entrepreneur, would bring his seven-yearold company, Exfluor Research Corporation, which previously only existed on paper as a legal entity, to fruition as a viable corporation.

From its inception, Exfluor focused its efforts on making fluorocarbons commercially available by synthesizing the compounds from hydrocarbons before expanding to develop specialty space lubricants, specialty coatings, and nonflammable hydraulic fluids to support research conducted by NASA and the US Air Force. The company would go on to hold more than 25 US patents for its fluorination processes and fluorinated products and would establish a second division in 1996, Fluoromed, which specializes in synthesizing fluorinated radiographic compounds used in medical diagnostics. 
These feats, however, came as no surprise to many who worked with the New Mexico native. The man was a visionary who knew no bounds. Perhaps no one benefited from his influence more than his students and mentees.

For Tom Bierschenk, meeting Dr. Lagow ultimately altered his educational path — and his career. "I was perfectly content with getting my bachelor's from The University of Texas at Austin, but he talked me into going back to school to get my PhD," said Bierschenk. But the duo's relationship did not end when Bierschenk successfully defended his doctoral dissertation in 1982. Often frustrated with the intricacies of fluorine chemistry, several of Dr. Lagow's students who focused their research on fluorination moved on to pursue other areas of science, but Bierschenk was open to pursuing new challenges in fluorine chemistry. Dr. Lagow asked him to join Exfluor, and with some hesitation, Bierschenk came onboard.

The first years were tough - and uncomfortable. Operating leanly meant the team never ran the air conditioning or heating in their small office space. They witnessed the arrivals and departures of neighboring companies whose management teams had purchased big, fancy executive desks and chairs. Exfluor conducted business affairs from a modest kitchen table.

Then, after five years of

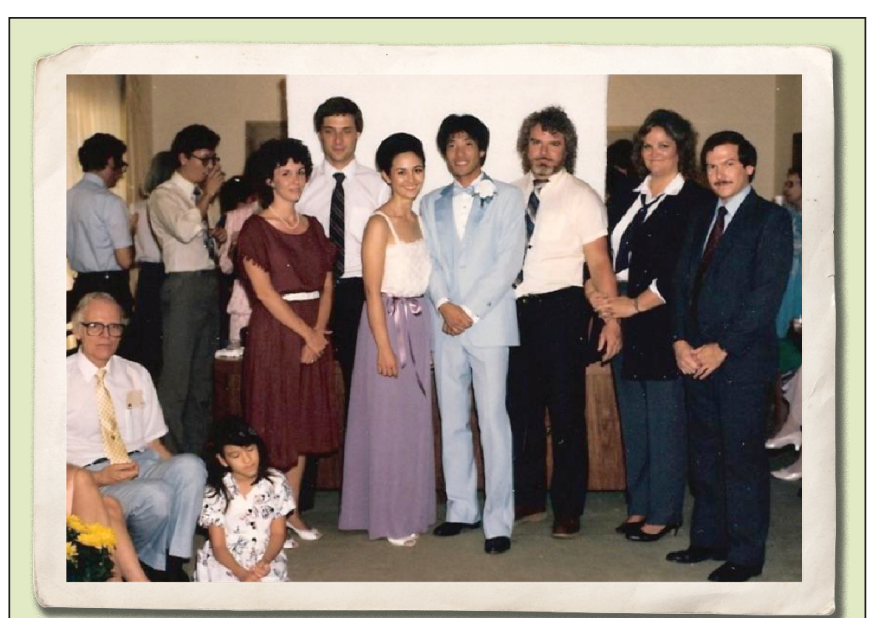

Known for his love of the finer things in life, Richard Lagow often treated his students to dinners at some of the finest restaurants Austin had to offer. Here he is at the wedding of one of his postdoctoral students, Hajimu Kawa (also a 34-year employee at Exfluor). (From left to right): Ann Bierschenk and her husband Tom Bierschenk, Nancy Parker, Hajimu Kawa, Richard Lagow, Bobbie D. Lagow, and Tim Juhlke (also an Exfluor employee). Photo: Courtesy of Tom and Ann Bierschenk. metal vapor chemistry. The scientist said Dr. Lagow's infectious energy is what ultimately attracted him to his laboratory.

"Dick was a really inspirational kind of character who had a contagious excitement about chemistry," recalled Battle, who joined Lagow's laboratory in 1986. "He was so excited about chemistry that you couldn't help but get excited, too."

Battle believed that Dr. Lagow's unconventional managerial style expanded his creativity with a higher and broader level of research. Lagow encouraged his mentees to incorporate their own ideas into their projects, whether it be a different approach or altering a step.

"He left me the latitude to explore some of my own areas of research interest within his metal group," said Battle. "You didn't get away with being a pair of hands with your projects handed to you on a silver platter in his lab. He wanted your creativity to be part of the mix as well."

Then, there is Jay Bender, MD, who had his sights set on becoming a physician at an early age. However, unlike most kids, Bender was one of the few people whose childhood dreams of completing medical school never faltered. While he fulfilled that dream, his route there altered the kind of physician he would become.

Astrong student who breezed through grade school as well as advanced placement testing for college credit, Bender assumed that getting into medical school would be equally as easy. But filling small orders for numerous specialty chemicals, Exfluor received their largest order to date: $40 \mathrm{~kg}$ of perfluorooctanol from Aldridge Chemical. The order prompted the duo to specialize in making the fluorinated compound, which allowed them to scale.

And with that, Bierschenk's career-hopping days came to a permanent end.

"Joining Exfluor and working with Dick gave me an opportunity to develop my leadership and entrepreneurial skills and learn the value of persistence," said Bierschenk on his 35-year tenure with Exfluor, where he has risen up in the ranks from director of research to vice president of the corporation.

Scott Battle was a master's student at Stephen F. Austin University in Nacogdoches, Texas, when he met Dr. Lagow at a seminar he gave at the institution in the mid-1980s. Intrigued by the diversity of Dr. Lagow's research projects (which ranged from developing a bone analogue from porous bioceramics, synthesizing nanotubes from elemental carbon using a laser that Dr. Lagow built himself, and fluorinating hydrocarbon compounds and surfactants), Battle ultimately settled into studying when his initial grades threatened to blemish his impeccable record, he realized he needed to find a way to recover - and quickly.

Bender stumbled across Dr. Lagow's laboratory when reviewing a list of courses that could boost his GPA. Intrigued by the idea of working with artificial bone materials, he soon found himself spending his weekends tending to the rabbits and other laboratory animals.

"To a large degree, that's how I went from wanting to be a pediatrician to becoming an orthopedic surgeon," said Bender, who graduated from The University of Texas at Austin with a degree in zoology and humanities in 1988.

Now an orthopedic surgeon specializing in adult reconstruction and trauma in Denton, Texas, Bender recalled a class in which Dr. Lagow drew a graph with peaks and valleys on the chalkboard.

"Don't spend your life on small accomplishments, he told us, pointing to the valleys," said Bender. "Do the big things that are going to change the world."

And that's just what Dr. Lagow did, one molecule and one student at a time.

Frieda Wiley 